\title{
Impact of UV radiation on plankton net community production: responses in Western Australian estuarine and coastal waters
}

\author{
Lara S. García-Corral ${ }^{1,3, *}$, Carlos M. Duarte ${ }^{2}$, Susana Agusti ${ }^{2}$ \\ ${ }^{1}$ The UWA Oceans Institute and School of Plant Biology, The University of Western Australia, Crawley, WA 6009, Australia \\ ${ }^{2}$ King Abdullah University of Science and Technology (KAUST), Red Sea Research Center (RSRC), Thuwal, 23955-6900, Saudi Arabia \\ ${ }^{3}$ Present address: Department of Biology, Geology, Physics and Inorganic Chemistry, King Juan Carlos University, \\ C/ Tulipán s/n, 28933 Madrid, Spain
}

\begin{abstract}
Net community production $(\mathrm{NCP})$ is a relevant parameter informing on the role of plankton communities as sinks or sources of $\mathrm{CO}_{2}$ in the ocean. We assessed the effect of ultraviolet (UV) radiation on NCP in different regions along the coast of Western Australia (WA). We compared 57 NCP measurements of surface communities receiving full-spectrum natural solar radiation, to communities with natural UVB radiation excluded ( $\left.\mathrm{NCP}_{-\mathrm{UV}}\right)$. Very high values of incident UVB radiation were registered, especially during spring and summer (up to $75 \mathrm{~kJ} \mathrm{~m}^{-2} \mathrm{~d}^{-1}$ ). Although a strong inhibitory effect of UVB on NCP was expected due to the high UVB levels, no significant differences between $\mathrm{NCP}$ and $\mathrm{NCP}_{\text {-Uv }}$ were observed in any sampled region. However, we found a general trend of NCP inhibition by $33.4 \%$ under UVB radiation along the WA coast. While NCP of autotrophic communities tended to slightly decrease under UVB radiation, no robust pattern was observed for heterotrophic communities. Experiments measuring the response of NCP exposed to a gradient of enhanced UVB doses exhibited a UV dose-dependent inhibition of NCP in estuarine communities (i.e. higher inhibition with higher UVB doses), and a UV dose-independent inhibition in coastal communities. Our in situ data showed that the net metabolism of surface plankton communities from the coast of WA was insignificantly affected by elevated environmental UVB radiation levels.
\end{abstract}

KEY WORDS: Plankton metabolism - Net community production · UVB radiation · Western Australia $\cdot$ Estuarine and coastal waters

\section{INTRODUCTION}

The stratospheric ozone concentration increases from the equator towards the poles, with an associated latitudinal and cloud cover variability of ultraviolet B (UVB) radiation (280-320 nm) incident on the sea surface (Sen Mandi 2016). The stratospheric ozone layer protects all living organisms from excess ultraviolet radiation (UVR); however, the destruction of this layer results in an increase in UVR levels (Molina \& Rowland 1974, Weatherhead \& Andersen 2006). The discovery of the ozone hole during the

${ }^{*}$ Corresponding author: lara.silvia.g@gmail.com 1980s led to great research efforts to understand its consequences, and to assess the effects of enhanced UVR on marine organisms and processes (Smith \& Baker 1989, Helbling \& Zagarese 2003, Llabrés et al. 2013). The reduction of the ozone layer is asymmetrical between hemispheres, and the stratospheric ozone concentration in the Southern Hemisphere is lower than that in the Northern Hemisphere (Seckmeyer \& McKenzie 1992, Agustí et al. 2015). Consequently, the southern part of the world has been receiving increased UVR for the past 3 decades, since the Antarctic ozone hole developed (Farman et al.

() The authors 2020. Open Access under Creative Commons by Attribution Licence. Use, distribution and reproduction are unrestricted. Authors and original publication must be credited. 
1985, Herman 2010). Global evaluations of the effects of UVR on marine biota show that planktonic organisms are affected by UVB (280-320 nm) across different biomes including temperate, subtropical and polar waters (Llabrés et al. 2013). Indeed, there is a bias in studies analysing the effects of UVB on organisms from the Northern Hemisphere (twothirds of studies) compared to the Southern Hemisphere (Agustí et al. 2015), and within the latter, most studies have been carried out in Antarctic waters, with fewer studies in mid-temperate regions (Agustí et al. 2015).

Plankton metabolism is a key biological component of the carbon cycle of the ocean, determining the role of plankton communities as sinks (gross primary production higher than community respiration, GPP > $\mathrm{CR}$ ) or sources (GPP $<\mathrm{CR}$ ) of $\mathrm{CO}_{2}$ in the ocean (del Giorgio \& Williams 2005). Therefore, the main metabolic processes of planktonic communities such as CR and GPP might be affected by UVB radiation, and consequently, the difference between GPP and CR, i.e. net community production (NCP), would also be affected. UVB radiation is a significant stressor in aquatic freshwater and marine environments, although its effects on NCP are not simple, possibly because NCP is an integrative property that brings together impacts at multiple levels. Studies have shown that UVB radiation inhibits surface NCP of the Atlantic, Southern and Pacific Oceans and the coastal Mediterranean Sea (Godoy et al. 2012, Agustí et al. 2014, Regaudie-de-Gioux et al. 2014, García-Corral et al. 2015). However, UV increased NCP of Arctic Ocean surface communities during summer (GarcíaCorral et al. 2014), and also modified NCP of the upper global Subtropical oceans, depending on the metabolic status and the amount of UV irradiance received (García-Corral et al. 2017). In surface estuarine waters, primary production measured with ${ }^{14} \mathrm{C}$ showed an inhibition rate of 3-33\% (Banaszak \& Neale 2001) and 15-47\% (Litchman \& Neale 2005) in shallow, eutrophic and turbid temperate estuaries. However, no reduction in primary production was observed in a hypertrophic Baltic Sea estuary (Forster \& Schubert 2001). Therefore, similar ecosystems responded differently to UVR, as many other factors (e.g. temperature, dissolved organic matter [DOM], community structure, nutrient status) can affect the diverse planktonic community responses to UVR.

The effect of UV on the NCP in the temperate coastal waters of the Southern Hemisphere, around Australia, has not been addressed to date. Here, we report the results of our studies on the effect of UVR on the net metabolism of plankton communities in coastal waters of Western Australia (WA), in which we examined the NCP of communities exposed to the ambient light environment and communities exposed to a light field where UVR was removed. To do so, we measured the incident irradiance and calculated UV doses received in the sampled areas and also experimentally tested the effects of artificially increasing daily UV doses on NCP. Our goal was to test whether UVR affects plankton net metabolism in surface waters of WA. Based on the previous literature, we expected that the strong UVR reaching WA coasts would affect and decrease the plankton net metabolic balance.

\section{MATERIALS AND METHODS}

\subsection{Observational study}

\subsubsection{Sampling sites}

We obtained 57 NCP measurements from surface waters (0.5-3 $\mathrm{m}$ ) along the coast of WA in the Eastern Indian Ocean. Samples were subclassified into 4 different regions: (1) Ningaloo area $\left(23^{\circ} \mathrm{S}\right.$; 2 stations), (2) Perth area $\left(31.9-33.6^{\circ} \mathrm{S}\right)$ including 1 station at Rottnest Island, 1 at Busselton and a fortnightly sampled station at $32^{\circ} \mathrm{S}$ (March 2014 to March 2015) at Woodman Point beach (23 measurements), (3) a fortnightly sampled station at $32^{\circ} \mathrm{S}$ at the Swan River Estuary (28 measurements) and (4) at the Southernmost region in Albany at $35^{\circ} \mathrm{S}$ (2 stations) (Fig. 1).

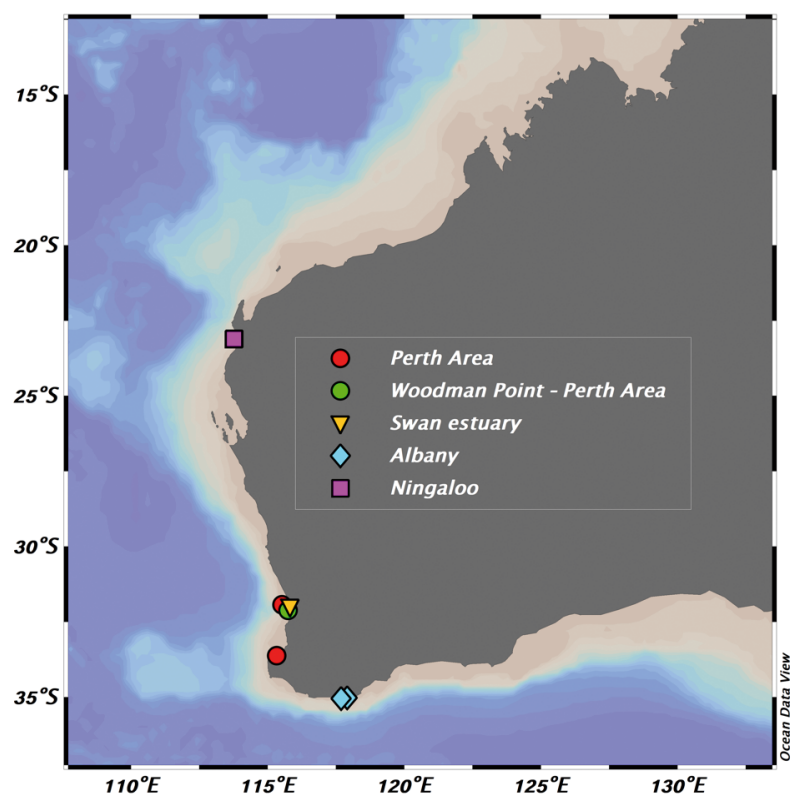

Fig. 1. Sampling sites along the coast of Western Australia 


\subsubsection{Plankton net community production}

At each station, surface $(0.5-3 \mathrm{~m})$ seawater was carefully siphoned into 10 calibrated narrow-mouthed borosilicate glass Winkler bottles and 5 calibrated quartz bottles $\left(100 \mathrm{~cm}^{3}\right)$ using a silicon tube. Five glass-bottle replicates were used to measure initial oxygen concentrations before incubation. The other 5 replicates of glass and 5 replicates of quartz bottles were incubated in situ at 0.5-1 m depth, except samples from Woodman Point beach and the Swan River Estuary that were incubated in outdoor temperaturecontrolled tanks at the UWA facilities. Both incubations received natural solar radiation underwater. The borosilicate glass bottles allowed $100 \%$ transmittance of photosynthetically active radiation $\left(\mathrm{PAR}_{i}\right.$ 400-700 nm) but removed almost all UVB, allowing the transmission of $0 \%$ at $280 \mathrm{~nm}$ up to $60 \%$ at $320 \mathrm{~nm}$ and a small part of UVA (320-400 nm), whereas quartz bottles allowed the transmittance of $100 \%$ PAR and $90 \%$ of UVB and UVA radiation (Godoy et al. 2012, Regaudie-de-Gioux et al. 2014). Hence, results derived from measurements conducted in quartz bottles were characteristic of the ambient light field, whereas those conducted in Winkler glass bottles tested the effect of reducing natural UVR.

Samples, both in situ and in the outdoor temperature-controlled tanks, were incubated for $24 \mathrm{~h}$ at the sampled water temperature and under natural solar radiation, to mimic the in situ conditions. After incubation, samples were fixed, and the final oxygen concentration was determined by automated high-precision Winkler titration (Carpenter 1965) with a Compact Titrator G20 (Mettler Toledo) based on a calibrated redox potentiometric end-point detection (Oudot et al. 1988). NCP rates, expressed as $\mathrm{mmol} \mathrm{O}_{2}$ $\mathrm{m}^{-3} \mathrm{~d}^{-1}$, were determined under full solar radiation and when UVR was excluded (hereafter NCP and $\mathrm{NCP}_{-U V}$, respectively); they were calculated from the difference between the oxygen concentrations measured in the incubated bottles for $24 \mathrm{~h}$ (glass or quartz), and concentrations measured in fixed samples at the beginning of the incubation period.

\subsection{Experimental UV gradient study}

We performed 6 experiments, 3 with Swan River Estuary surface waters on 1, 7 and 15 October 2015 and 3 with surface coastal waters from Woodman Point beach (Fig. 1) on 5, 12 and 20 October 2015 to test NCP responses to a gradient of increased UVB doses. NCP was determined under a gradient of UVB light treatments. Samples were incubated at in situ temperature in a large controlled-temperature water bath inside a glass greenhouse located in the UWA plant growth facility. Inside the greenhouse, incident solar UVB radiation was filtered out by the glass structure. It is likely that most of the short wavelength UVA radiation was also filtered out, although we did not quantify this; however, solar PAR was received. UVB radiation was artificially added by using UVB lamps (312 nm, Vilber VL-8.M; Fisher biotec). The UVB lamps were hooked from a metal structure over the tank at different heights to create 3 underwater UVB dose treatments: low UVB $\left(16.2 \mathrm{~kJ} \mathrm{~m}^{-2} \mathrm{~d}^{-1}, 0.09 \mathrm{~mW}\right.$ $\mathrm{cm}^{-2}, 33 \mathrm{~cm}$ from the tank to the lamp), mid-low

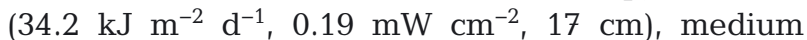
$\left(50.4 \mathrm{~kJ} \mathrm{~m}^{-2} \mathrm{~d}^{-1}, 0.28 \mathrm{~mW} \mathrm{~cm}^{-2}, 11 \mathrm{~cm}\right)$ and high UVB $\left(66.6 \mathrm{~kJ} \mathrm{~m}^{-2} \mathrm{~d}^{-1}, 0.37 \mathrm{~mW} \mathrm{~cm}^{-2}, 8 \mathrm{~cm}\right)$. The range of underwater UVB doses were based on the $25^{\text {th }}, 50^{\text {th }}$, $75^{\text {th }}$ and $90^{\text {th }}$ percentiles of the incident solar UVB radiation doses measured in the field. The lamps were on for $5 \mathrm{~h}$ (from 10:30 to 15:30 h), and when the lamps were switched off, all samples received filtered solar radiation for the duration of the local photoperiod. Long-wavelength UVC emissions from the lamps were filtered out by the water bath. We tested $\mathrm{NCP}_{-\mathrm{UV}}$ treatments by incubating samples in glass borosilicate bottles and with no exposure to UVB radiation, and $\mathrm{NCP}_{\mathrm{PAR}+\mathrm{UVB}}$ treatments by incubating the samples in quartz bottles at the different UVB treatments. Five replicate bottles for each light treatment were incubated for $24 \mathrm{~h}$ at in situ water temperature. The oxygen concentration in the light-treatment bottles was measured after the incubation, and the initial concentration of oxygen was measured in 5 replicates following the method described in Section 2.1.2.

\subsection{Biogeochemical and physical parameters}

Environmental surface incident PAR and UVB measurements were obtained with a company-calibrated Solar Light radiometer (Model PMA2100), coupled to pre-calibrated digital sensors measuring the electromagnetic spectrum of PAR (PMA2132; 400$700 \mathrm{~nm}$ ) and a UVB band (PMA2106; 280-320 nm). Sensors were located at the same height and close to the incubation point without shading. PAR and UVB daily doses $\left(\mathrm{kJ} \mathrm{m}^{-2} \mathrm{~d}^{-1}\right)$ were calculated as the sum of the surface radiation received during the incubation period. UV index values measured in air were obtained from the Australian Radiation Protection and Nuclear Safety Agency website (https://www.arpansa. gov.au) for each sampled day and location. 
Chlorophyll a ( $\mathrm{chl}$ a) concentration was determined by filtering a 100-300 ml water sample through a $25 \mathrm{~mm}$ GF/F glass microfibre filter (Whatman ${ }^{\circledR}$; nominal pore size of $0.7 \mu \mathrm{m}$ ) and extracting chl $a$ for $24 \mathrm{~h}$ within $90 \%$ acetone. Chl a concentration $\left(\mathrm{mg} \mathrm{m} \mathrm{m}^{-3}\right.$ ) was derived from the fluorescence of the extracts measured using a pre-calibrated nonacidification module in a Trilogy fluorometer (Turner Designs). Water temperature, salinity, dissolved oxygen, conductivity and $\mathrm{pH}$ were recorded with a calibrated YSI EXO1 Multi-parameter Water Quality Sonde (Agusti et al. 2018).

\subsection{Data analysis and statistics}

All data were recorded in Microsoft Excel and analysed with the statistical package program JMP version 9.0.1. A Shapiro-Wilk test was conducted to assess the normal distribution of each set of data; in all cases, the p-value was found to be less than 0.05 . Nonparametric tests, including all-pairs Steel-Dwass tests, Wilcoxon paired-sample tests and KruskalWallis tests, were performed to reveal any signifi- cant differences between treatments and to test our initial hypothesis. A Model II regression was fitted to evaluate the linear relationship between variables. The software Ocean Data View version 4.6.3 (Schlitzer 2013) was used to create the map of the sampled areas. Means \pm SEM are reported.

\section{RESULTS}

\subsection{Environmental parameters}

The sampled areas showed higher temperatures in the tropical northwest region of Ningaloo (23.4 \pm $0.44^{\circ} \mathrm{C}$ ), and lower and similar temperatures in the southwest regions: Swan Estuary $\left(20.67 \pm 0.62^{\circ} \mathrm{C}\right)$, Perth area $\left(20.5 \pm 0.55^{\circ} \mathrm{C}\right)$ and Albany $(20.5 \pm$ $0.50^{\circ} \mathrm{C}$ ) (Fig. 1, Table 1). Salinity was uniform for marine regions $(\sim 35)$ but varied widely at the Swan Estuary, exhibiting low salinity (22) after winter rains, and high salinities (37) during summer, because of the strong evaporation (Table 1). The maximum UV index registered was high across the sampling areas, ranging from 10 to 12 , with the lowest

Table 1. Sampled areas in Western Australia: number of measurements (N), latitude and longitude range, sampling dates, water temperature, salinity, UV index, UVB doses and chlorophyll a concentration

\begin{tabular}{|c|c|c|c|c|c|}
\hline Variable & & Albany & Perth area & Swan River Estuary & Ningaloo \\
\hline $\mathrm{N}$ & & 2 & 25 & 28 & 2 \\
\hline Latitude $\left({ }^{\circ} \mathrm{S}\right)$ & $\begin{array}{l}\text { Min } \\
\text { Max }\end{array}$ & $\begin{array}{l}35.07 \\
35.03\end{array}$ & $\begin{array}{l}33.63 \\
31.94\end{array}$ & $\begin{array}{l}31.99 \\
31.99\end{array}$ & $\begin{array}{l}23.16 \\
23.11\end{array}$ \\
\hline Longitude $\left({ }^{\circ} \mathrm{E}\right)$ & $\begin{array}{l}\text { Min } \\
\text { Max }\end{array}$ & $\begin{array}{l}117.69 \\
117.92\end{array}$ & $\begin{array}{l}115.34 \\
115.75\end{array}$ & $\begin{array}{l}115.82 \\
115.82\end{array}$ & $\begin{array}{l}113.76 \\
114.1\end{array}$ \\
\hline Dates & & November 2014 & $\begin{array}{c}\text { March } 2014 \\
\text { to March } 2015\end{array}$ & $\begin{array}{c}\text { March } 2014 \\
\text { to March } 2015\end{array}$ & October 2014 \\
\hline Temperature $\left({ }^{\circ} \mathrm{C}\right)$ & $\begin{array}{c}\text { Mean } \pm \text { SEM } \\
\text { Min } \\
\text { Max } \\
\text { Median }\end{array}$ & $\begin{array}{l}20.50 \\
20.00 \\
21.00 \\
20.50\end{array}$ & $\begin{array}{c}20.50 \pm 0.55 \\
15.10 \\
25.00 \\
21.20\end{array}$ & $\begin{array}{c}20.67 \pm 0.62 \\
14.30 \\
25.50 \\
20.65\end{array}$ & $\begin{array}{l}23.40 \\
23.00 \\
23.80 \\
23.40\end{array}$ \\
\hline Salinity & $\begin{array}{c}\text { Mean } \pm \text { SEM } \\
\text { Min } \\
\text { Max } \\
\text { Median }\end{array}$ & $\begin{array}{l}35.14 \\
35.14 \\
35.14 \\
35.14\end{array}$ & $\begin{array}{c}35.15 \pm 0.29 \\
31.62 \\
36.88 \\
35.02\end{array}$ & $\begin{array}{c}32.12 \pm 0.97 \\
22.03 \\
36.97 \\
34.35\end{array}$ & $\begin{array}{l}35.44 \\
35.44 \\
35.44 \\
35.44\end{array}$ \\
\hline UV index & Max & 10.00 & 12.00 & 12.00 & 11.00 \\
\hline UVB dose $\left(\mathrm{kJ} \mathrm{m}^{-2} \mathrm{~d}^{-1}\right)$ & $\begin{array}{c}\text { Mean } \pm \text { SEM } \\
\text { Min } \\
\text { Max } \\
\text { Median }\end{array}$ & $\begin{array}{l}51.38 \\
51.38 \\
51.38 \\
51.38\end{array}$ & $\begin{array}{c}37.78 \pm 4.43 \\
7.63 \\
72.37 \\
35.07\end{array}$ & $\begin{array}{c}41.41 \pm 3.67 \\
7.74 \\
75.05 \\
39.25\end{array}$ & $\begin{array}{l}70.48 \\
70.48 \\
70.48 \\
70.48\end{array}$ \\
\hline Chlorophyll a $\left(\mathrm{mg} \mathrm{m}^{-3}\right)$ & $\begin{array}{c}\text { Mean } \pm \text { SEM } \\
\text { Min } \\
\text { Max } \\
\text { Median }\end{array}$ & $\begin{array}{l}0.35 \\
0.13 \\
0.58 \\
0.35\end{array}$ & $\begin{array}{c}1.52 \pm 0.15 \\
0.28 \\
3.40 \\
1.55\end{array}$ & $\begin{array}{c}3.69 \pm 0.33 \\
1.29 \\
8.47 \\
3.21\end{array}$ & $\begin{array}{l}0.19 \\
0.16 \\
0.22 \\
0.19\end{array}$ \\
\hline
\end{tabular}


maximum value (10) registered at Albany and the highest at the Swan Estuary and in the Perth area (12). Overall, UV daily doses ranged from the lowest winter measurements of $7.63 \mathrm{~kJ} \mathrm{~m}^{-2} \mathrm{~d}^{-1}$ in the Perth area, to the high levels of $75.05 \mathrm{~kJ} \mathrm{~m}^{-2} \mathrm{~d}^{-1}$ registered at the Swan Estuary during summer. An analysis of the entire dataset showed that spring and summer registered significantly higher (Steel-Dwass test, $\mathrm{p}<$ 0.05 ) UV daily doses, compared to autumn and winter (Table 1, Fig. 2).

$\mathrm{Chl}$ a values were significantly higher $(\mathrm{p}<0.05)$ at the Swan Estuary (ranging from 1.29 to $8.47 \mathrm{mg} \mathrm{m}^{-3}$ ), whereas the lowest concentrations were registered at Ningaloo (0.16-0.22 $\mathrm{mg} \mathrm{m}^{-3}$ ) (Table 1).

\subsection{Observational study results}

Mean surface $\mathrm{NCP}_{-\mathrm{uv}}$ was higher and net autotrophic at the Swan Estuary $\left(6.81 \pm 1.06 \mathrm{mmol} \mathrm{O}_{2} \mathrm{~m}^{-3}\right.$ $\left.\mathrm{d}^{-1}\right)$, followed by the open coast of the Perth area $\left(1.79 \pm 0.66 \mathrm{mmol} \mathrm{O}_{2} \mathrm{~m}^{-3} \mathrm{~d}^{-1}\right)$ and Ningaloo $(1.29 \pm$ $4.48 \mathrm{mmol} \mathrm{O}_{2} \mathrm{~m}^{-3} \mathrm{~d}^{-1}$ ), and lower and net heterotrophic at Albany $\left(-0.67 \pm 4.08 \mathrm{mmol} \mathrm{O}_{2} \mathrm{~m}^{-3} \mathrm{~d}^{-1}\right)$. Surface NCP under full solar radiation followed a similar pattern as $\mathrm{NCP}_{-\mathrm{UV}}$, with higher values measured at the Swan Estuary $\left(5.62 \pm 0.93 \mathrm{mmol} \mathrm{O}_{2} \mathrm{~m}^{-3} \mathrm{~d}^{-1}\right)$ in comparison with the Perth area $\left(1.86 \pm 0.57 \mathrm{mmol} \mathrm{O}_{2}\right.$ $\left.\mathrm{m}^{-3} \mathrm{~d}^{-1}\right)$, Ningaloo $\left(1.03 \pm 4.81 \mathrm{mmol} \mathrm{O}_{2} \mathrm{~m}^{-3} \mathrm{~d}^{-1}\right)$ and the heterotrophic region of Albany $(-1.79 \pm 1.82$ $\mathrm{mmol} \mathrm{O}_{2} \mathrm{~m}^{-3} \mathrm{~d}^{-1}$ ) (Fig. 3). However, within each sampled area, the surface NCP and $\mathrm{NCP}_{- \text {Uv }}$ rates (mmol $\mathrm{O}_{2} \mathrm{~m}^{-3} \mathrm{~d}^{-1}$ ) were not significantly different (Fig. 3).

Although no significant differences were observed between $\mathrm{NCP}$ and $\mathrm{NCP}_{-\mathrm{UV}}$ in any of the sampled regions, there was a general linear relationship between $\mathrm{NCP}_{-\mathrm{UV}}$ and NCP (Fig. 4), with a significant tendency for $\mathrm{NCP}_{-\mathrm{UV}}$ to be higher than NCP (Wilcoxon paired $t$-test, $t=-2.18, \mathrm{df}=56, \mathrm{p}<0.05$ ), as also confirmed by the fitted regression equation, $\mathrm{NCP}=0.79$ $( \pm 0.04) \times \mathrm{NCP}_{-U V}+0.25( \pm 0.30)\left(\mathrm{R}^{2}=0.85, \mathrm{p}<0.0001\right.$ ， $\mathrm{n}=57$, Fig. 4). NCP declined on average by $33.4 \%$ under UVB radiation, compared with $\mathrm{NCP}_{-\mathrm{UV}}$, with a mean difference between $\mathrm{NCP}$ and $\mathrm{NCP}_{-\mathrm{UV}}$ across regions of $-0.6 \pm 0.27 \mathrm{mmol} \mathrm{O}_{2} \mathrm{~m}^{-3} \mathrm{~d}^{-1}$.

No significant differences were observed between the effect size (i.e. $\left[\mathrm{NCP}_{- \text {UV }}-\mathrm{NCP}\right] / \mathrm{NCP}_{- \text {UV }}$ ) and the differences (NCP - $\mathrm{NCP}_{- \text {UV }}$ vs. NCP) with the community trophic status ( $t$-test, $\mathrm{p}>0.05)$. However, a closer inspection of the linear regression showed that $\mathrm{NCP}$ under full solar radiation tended to be lower than $\mathrm{NCP}_{\text {-UV }}$ when the plankton community was net autotrophic (NCP >0), whereas NCP tended to be

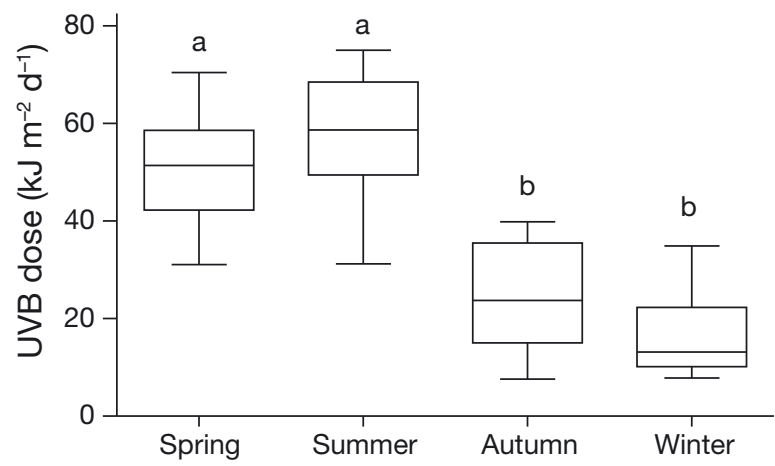

Fig. 2. Calculated UVB doses $\left(\mathrm{kJ} \mathrm{m}^{-2} \mathrm{~d}^{-1}\right)$ by austral season along the sampled Western Australian coastal areas. The boxes show the central horizontal line which represents the median UVB dose, and the lower and upper edges represent the 25th and 75th percentiles, respectively. Whiskers indicate 1.5 times the Interquartile Range (IQR). Lower case letters indicate the Tukey HSD test, where seasons not connected by the same letter are significantly different

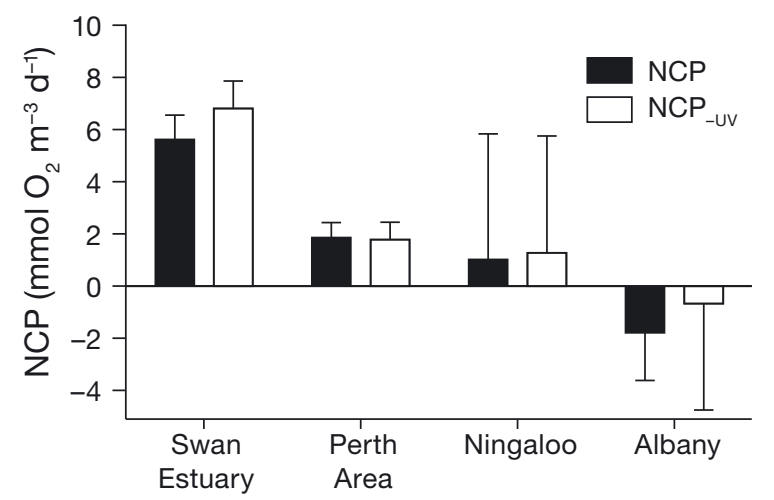

Fig. 3. Mean ( \pm SEM) of net community production under full solar radiation (NCP) and when UVB was excluded $\left(\mathrm{NCP}_{-\mathrm{UV}}\right)$ at the sampled areas

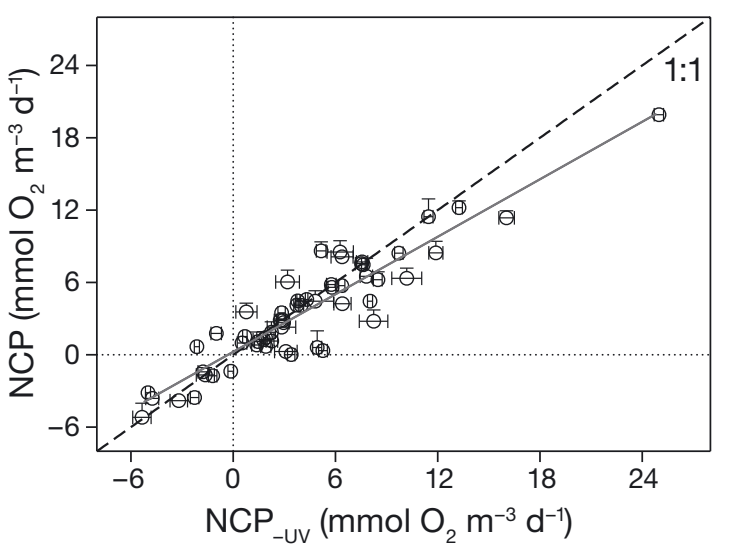

Fig. 4. Relationship for all sampled communities between net community production under natural full solar radiation (NCP) and NCP when UVB radiation was excluded $\left(\mathrm{NCP}_{-\mathrm{UV}}\right)$. The solid line represents the fitted Type II regression equation: $\mathrm{NCP}=0.79( \pm 0.04) \times \mathrm{NCP}_{-\mathrm{UV}}+0.25( \pm 0.30)$ $\left(\mathrm{R}^{2}=0.85, \mathrm{p}<0.0001, \mathrm{n}=57\right)$. The dashed line indicates the 1:1 line and dotted lines mark the thresholds where NCP and $\mathrm{NCP}_{-\mathrm{UV}}$ are equal to zero. Means $\pm \mathrm{SEM}$ are shown 
equal or slightly higher than $\mathrm{NCP}_{\text {-UV }}$ when the community was net heterotrophic ( $\mathrm{NCP}<0$ ) (Fig. 4). NCP of heterotrophic communities was close to zero and only found at 9 stations compared to the 48 autotrophic communities, and therefore the results are not robust enough to confirm a pattern.

\subsection{Experimental UVB gradient results}

The experiments tested the responses of surface NCP to the supplemented gradient of artificial UVB radiation (Fig. A1 in Appendix 1). PAR daily doses $\left(\mathrm{kJ} \mathrm{m}^{-2}\right)$ received during the experiments by the Swan Estuary communities were 7810, 7541 and $6865 \mathrm{~kJ}$ $\mathrm{m}^{-2}$ on the first, second and third experimental day, respectively. For the coastal Woodman Point communities, PAR doses were 8491, 6685 and $12798 \mathrm{~kJ} \mathrm{~m}^{-2}$, respectively. The communities tested showed similar initial exposure conditions: the UV index was 8 at both sites at the sampling time in all experiments, except the last sample (3rd experiment) from Woodman Point, in which the UV index was 9.

In general, the communities tested showed a tendency for NCP to decrease as underwater UVB doses increased. Four of the 6 experiments showed a lower $\mathrm{NCP}$, as a result of an increase in UVB doses; in 2 of them, NCP changed from autotrophic (NCP $>0$ ) to heterotrophic (NCP < $)$ when UVB increased (Fig. A1). The 3 experiments with the Swan Estuary communities exposed to a gradient of artificial UVB doses showed a strong pattern of decreasing NCP as UVB doses increased. The other set of experimental incubations with the Woodman Point communities showed larger variability in NCP responses to increased UVB levels (Fig. A1). The third experiment (20 October) with Woodman Point communities showed a similar pattern to that obtained for the Swan Estuary communities, i.e. a linear decrease of $\mathrm{NCP}$ with elevated UVB doses. However, the previous 2 experiments (on 5 and 12 October) showed opposite trends.

The effect size of UVB on NCP, i.e. $\left(\mathrm{NCP}_{-\mathrm{UV}}-\mathrm{NCP}\right) /\left(\mathrm{NCP}_{-\mathrm{UV}}\right)$, was strongly dependent on the UVB dose received for the Swan Estuary communities $\left(\mathrm{R}^{2}=\right.$ $0.98, \mathrm{p}=0.008$ ), with the magnitude of the effect size of NCP increasing at higher daily UVB doses (Fig. 5). However, this was not observed in the communities from Woodman Point, where the effect size was independent from the doses ( $p>0.05$ ) (Fig. 5).

\section{DISCUSSION}

The results presented here show that net community metabolism in coastal surface waters of WA tended to be net autotrophic. In our study, the surface waters of the Eastern Indian Ocean coast showed that NCP was generally higher when UV radiation was removed (i.e. $\mathrm{NCP} \leq \mathrm{NCP}_{\text {-Uv }}$ ) and therefore our hypothesis is supported. Nevertheless, the inhibitory effect of UV on NCP was only observed for those communities with a net autotrophic balance $(\mathrm{NCP}>0)$.

This effect has also been described for the Mediterranean Sea (Regaudie-de-Gioux et al. 2014, GarcíaCorral et al. 2015), Atlantic, Pacific and Antarctic plankton communities (Godoy et al. 2012, Agustí et al. 2014, Regaudie-de-Gioux et al. 2014) and for the global subtropical regions of the Indian, Pacific and Atlantic Oceans (García-Corral et al. 2017). The mean difference of $\mathrm{NCP}-\mathrm{NCP}_{-\mathrm{Uv}}$ at the WA coast was $-0.6 \pm 0.27 \mathrm{mmol} \mathrm{O}_{2} \mathrm{~m}^{-3} \mathrm{~d}^{-1}$, not significantly different from the mean values reported for Subtropical Indian, Atlantic and Pacific communities exposed to lower UVB doses (Table 1 in García-Corral et al. 2017). Indeed, the ultraoligotrophic nature of the subtropical waters might explain the lower values found for both $\mathrm{NCP}$ and $\mathrm{NCP}_{-\mathrm{UV}}$, compared to the more productive waters of the WA coast sampled in this study.

The relationship between $\mathrm{NCP}$ and $\mathrm{NCP}_{-\mathrm{UV}}$ had a slope of $0.79 \pm 0.04$ (SE) (Fig. 4), not significantly different (ANCOVA $F$-test $\mathrm{p}>0.05$ ) from the slope described for the surface Indian Ocean of $0.88 \pm 0.08$ (García-Corral et al. 2017) and $0.61 \pm 0.18$ (SE) found for the global tropical and subtropical surface communities (García-Corral et al. 2017). In our study, $\mathrm{NCP}$ of autotrophic communities clearly tended to decrease under natural UVB radiation (i.e. NCP <

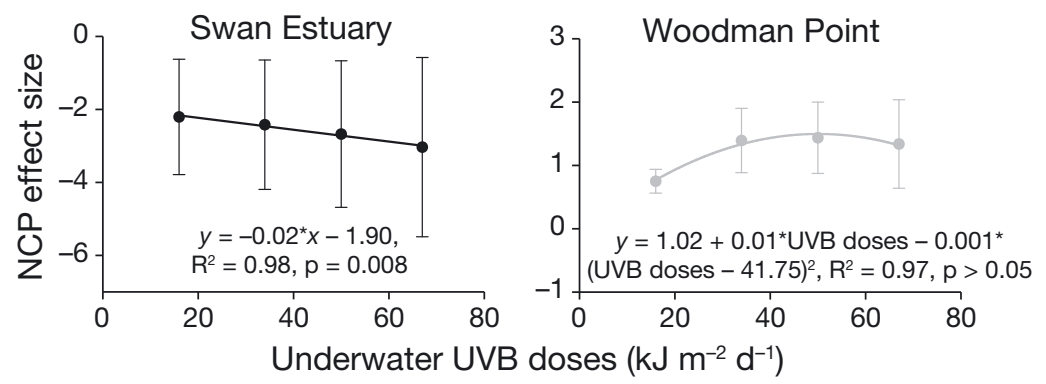

Fig. 5. Mean ( \pm SEM) effect size $\left(\left[\mathrm{NCP}_{-\mathrm{UV}}-\mathrm{NCP}\right] / \mathrm{NCP}_{-\mathrm{UV}}\right.$, where NCP is net community production under UVB and photosynthetically active radiation [PAR] and $\mathrm{NCP}_{-\mathrm{UV}}$ is NCP of communities exposed only to PAR) in response to the experimental gradient of increasing daily doses of UVB (from lamps) received underwater, tested on plankton communities from the Swan River Estuary and Woodman Point 
$\mathrm{NCP}_{- \text {Uv }}$ ), whereas the NCP of heterotrophic communities tended to stay equal or a slightly higher (i.e. $\mathrm{NCP} \geq \mathrm{NCP}_{-\mathrm{UV}}$ ).

Overall, in situ communities showed, on average, a decrease of NCP by $33.4 \%$ compared to $\mathrm{NCP}_{- \text {UV. }}$. On the one hand, a decline in NCP under natural UV and autotrophic conditions could be due to a reduction in phytoplankton growth rates and biomass of UV-sensitive species (Villafañe et al. 2003), as well as changes in the abundance and community taxonomic composition (Helbling et al. 1992, Behrenfeld et al. 1993a,b, Weinbauer et al. 1997, Keller et al. 1997, Wängberg et al. 1999, Garde \& Cailliau 2000, Barbieri et al. 2002, Villafañe et al. 2004, Litchman \& Neale 2005). UV-induced inhibition of primary production varied from $10-30 \%$ in coastal waters (Helbling \& Zagarese 2003), 5-44\% in Antarctic phytoplankton assemblages (Holm-Hansen et al. 1993, Boucher \& Prézelin 1996), 15-55\% in the open ocean (Helbling et al. 1992, Conan et al. 2008, Li et al. 2011, Fuentes-Lema et al. 2015) and about $32-42 \%$ in the oligotrophic Mediterranean Sea (Bertoni et al. 2011). Indeed, the UV-induced inhibition of primary production might also be explainable by the cellular damage caused to the oxygen-electron transport components of photosystem II, such as D1/D2 proteins (Vass et al. 1996, Sass et al. 1997, Kataria et al. 2014) that cannot be counteracted by cellular repair (Neale et al. 2014).

On the other hand, NCP can decrease if UVR increases CR. Respiration can be enhanced through the photolysis of DOM and dissolved organic carbon, providing more bioavailable and labile carbon and nutrients for heterotrophic organisms (Moran \& Zepp 1997, Zepp et al. 2007, Carrillo et al. 2015, FuentesLema et al. 2015). UV exposure enhances plankton community respiration during dark hours (Agustí et al. 2014). Thus, during the night, bacterioplankton activity and growth increased, using DOM released by phytoplankton mortality induced by UVR during the day (Llabrés \& Agustí 2006, Llabrés et al. 2010).

Finally, UV exposure can also reduce NCP when both processes (GPP and CR) are inhibited, albeit at a different rate, if inhibition of phytoplankton production is proportionally higher than the inhibition of bacterioplankton activity (Kaiser \& Herndl 1997, Ogbebo \& Ochs 2008). UVB can also reduce community respiration, as it affects the activity and functions of heterotrophic organisms such as bacterioplankton and viruses (Jeffrey et al. 1996, Huot et al. 2000, Wilhelm et al. 2003). UV can induce cellular and molecular damage (Mora et al. 2000, Sobrino et al. 2004, Llabrés \& Agustí 2006, Llabrés et al. 2010), changes in the bacterioplankton community composition (Arrieta et al. 2000), decreases in bacterial abundance and inhibition of bacterial production and respiration (Herndl et al. 1993, Müller-Niklas et al. 1995, Kaiser \& Herndl 1997, Ogbebo \& Ochs 2008, Bertoni et al. 2011), and generally increases mortality rates in heterotrophic marine microorganisms (Llabrés et al. 2013).

Regarding the experiments involving exposure to a UVB gradient, we observed some differences between days and places. At Woodman Point, during the first experiment (5 October), the weather was completely different from the other 2 sampled days. Therefore, the strong wind, high turbidity and vertical mixing water may have influenced the observed lower inhibition effect of UVB on NCP (Bertoni et al. 2011). On the second sampling date (12 October), the NCP showed a typical photoinhibition response curve (Jokiel \& York 1984, Yamamoto 2016), where NCP increased with UVB; however, above the optimal threshold, NCP decreased. This is consistent with the repair rate of phytoplankton, which increases gradually with irradiance until a maximum is reached, and above this maximum, the chronic damage due to high irradiance cannot be counteracted by the repair rate (Neale et al. 2014). At this stage, negative effects accumulate, leading to the breakdown of cellular metabolism.

Moreover, the observed different responses between coastal and estuarine communities with respect to UVB doses are difficult to elucidate, although several effects may partially explain the differences. Firstly, differences in water turbidity or transparency are key in determining the attenuation and penetration of the radiation into the water and therefore the potential sensitivity and impact of UVB on the communities (Tedetti \& Sempéré 2006). The Swan Estuary is characterized by more turbid, murky waters, and the resident communities might be acclimated to lower-light conditions and therefore could be more sensitive to increased doses of UVB (Villafañe et al. 2004, 2008, Litchman \& Neale 2005). In contrast, communities of the clear waters at Woodman Point might be adapted to receive higher UVB radiation, with more efficient repair processes and less sensitivity to increased UVB doses.

Secondly, the seasonal light-history of the communities might influence the NCP response. We observed significant differences in the UVB radiation measured during the year, with higher UVB doses during spring and summer (Fig. 2). However, we performed the experiments during springtime (October) when these communities started to receive higher 


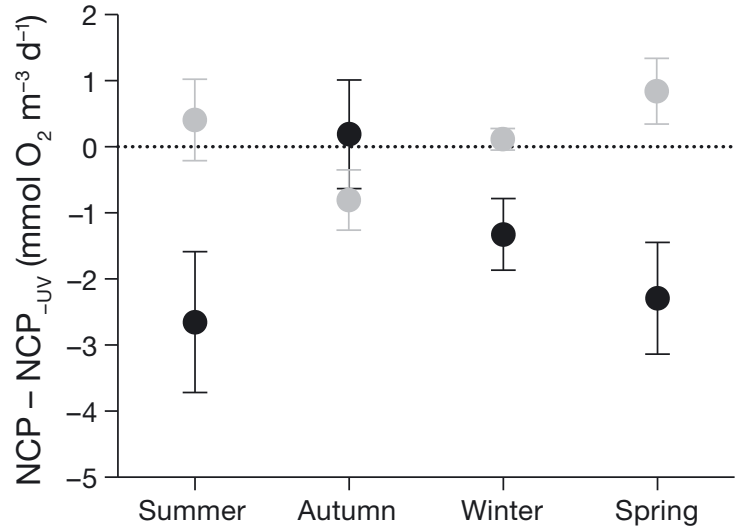

Fig. 6. Difference between mean net community production (NCP) ( \pm SEM) under full solar radiation and when UVB was removed $\left(\mathrm{NCP}_{-\mathrm{UV}}\right)$ by austral season for communities at the Swan River Estuary (black symbols) and Woodman Point (grey symbols)

natural UVB radiation, but they would have been exposed to very low irradiances during the previous winter and autumn (Fig. 2). Accordingly, we observed that for the in situ Swan Estuary communities, the strongest response ( $\mathrm{NCP}-\mathrm{NCP}_{-\mathrm{UV}}$ ) was during spring and summer (Fig. 6). The manipulated estuarine communities likely showed stronger effects of UVB on NCP than the in situ communities because of the light-history of the sampled communities. Therefore, if the experiments were performed in autumn after the high UVB received during spring and summer seasons, the estuarine communities might show lower or no effect of increased UVB doses on NCP. However, at the coastal Woodman Point area, NCP was differently and less affected by the experimentally increased UVB doses, and the in situ communities showed a similar low response, such that $\mathrm{NCP}-\mathrm{NCP}_{-\mathrm{Uv}}$ was close to zero across seasons (Fig. 6). Moreover, a short exposure to high UVB irradiance is more cell-damaging than a longer exposure to a lower irradiance (Cullen \& Lesser 1991). Thus, a stronger effect on NCP is expected because these communities were receiving low UVB radiation during a long period (winter and autumn).

Finally, we cannot ignore the differences in trophic and community composition between ecosystems. On the one hand, the dissolved nutrient concentrations are a key environmental factor in the response to UVR (Häder 2011, Beardall et al. 2014, Cabrerizo et al. 2014). The Swan Estuary waters are nutrient-rich compared to the nutrient-limited waters of Woodman Point (Agusti et al. 2018). Nutrient-enhanced waters can counteract or unmask the inhibitory effects of solar UVR on phytoplankton photosynthesis (Carrillo et al. 2015, Villafañe et al. 2017); however, we found stronger negative effects in the nutrient-rich estuarine waters compared to coastal waters. Indeed, under oligotrophic or low nutrient concentrations, UV can exert a negative impact on phytoplankton species, decreasing photosynthesis and quantum yield of photosystem II (Cabrerizo et al. 2014), and increasing the sensitivity of photosynthesis as a repair mechanism is less efficient (Litchman et al. 2002). On the other hand, community composition can respond differently; for example, plankton assemblages inhabiting the open ocean and clear waters can be more adapted to high UVR than the estuarine communities in darker and less transparent waters (Fritz et al. 2008, Harrison et al. 2015). Therefore, Woodman Point communities might suffer less of a negative inhibitory effect of NCP under UVR compared to the consistent pattern observed in the Swan Estuary communities.

Since the Antarctic ozone hole was described in the 1980s (Farman et al. 1985), and over the past 3 decades, the Southern Hemisphere has been receiving higher UVR than the Northern Hemisphere (Herman 2010). Thus, surface plankton communities from the Southern Hemisphere have been exposed to higher UV irradiances, and the long exposure period may have resulted in an adaptation and selection of more resistant organisms (Agustí et al. 2015). Based on our data, we postulate that plankton communities from the WA coastal communities might be photoacclimated and adapted to increased UVR, as described for similar latitudinal ranges in South Pacific waters (Montecino \& Pizarro 1995). It is known that phytoplankton species have the capacity to develop photoacclimation and photoprotective strategies to UVR, by increasing pigmentation or by developing high contents of mycosporine-like amino acids, chemicals that have a high UVR-absorbing capacity and high antioxidant capacity (e.g. Navarro et al. 2014, Shang et al. 2018). In addition, strategies such as structural changes in the community composition and increases in cell aggregation that provide self-shading contribute to UVR tolerance (Navarro et al. 2008).

Overall, these observations suggest that plankton communities from WA waters are not as strongly affected by the high UVR received, compared to the stronger negative response of plankton communities over the global ocean receiving much lower UVR doses (Godoy et al. 2012, Agustí et al. 2014, GarcíaCorral et al. 2014, 2015, 2017, Regaudie-de-Gioux et al. 2014). We observed smaller differences between $\mathrm{NCP}$ and $\mathrm{NCP}_{-\mathrm{UV}}$ than expected, given the high measured UVR. When UVB was artificially increased, we found a UV dose-dependent inhibition 
of NCP in estuarine communities (i.e. higher inhibition with higher UVB doses), while NCP of the coastal communities was less affected by UVB, only occasionally showing dose-dependent inhibition.

Therefore, based on all of the above, we conclude that UVR plays an important role in biological processes, from an evolutionary perspective. In the case of marine biota in the Southern Hemisphere, exposure to high UV irradiance (Häder et al. 2007, Herman 2010) resulted in the selection of plankton communities that are more resistant and adapted to UV, compared to those from the Northern Hemisphere (García-Corral et al. 2014), as described for a variety of organisms and processes (Agustí et al. 2015). The most recent scientific assessment concluded that there is enough evidence showing the negative effects of the stratospheric ozone depletion on Southern Ocean marine ecosystems (Williamson et al. 2019, World Meteorological Organization 2019). Moreover, the ozone in the lower stratosphere between $60^{\circ} \mathrm{S}$ and $60^{\circ} \mathrm{N}$, contrary to the upper stratospheric ozone layer, has declined since 1998 (Ball et al. 2018). Because we cannot ignore the existing threat, we believe it is essential to perform more UVexposure experiments with natural sunlight, increase monitoring data and incorporate UV photoinhibition into models of primary production in the world's oceans (Neale \& Thomas 2017) in order to understand the ultimate overall effects of UVR on marine ecosystems.

Acknowledgements. We thank María Comesaña and Lorena Vigoya for their assistance with sampling. This research was funded by the Australian Research Council's Discovery Project (project number DP140100825) and King Abdullah University of Science and Technology (KAUST) baseline funding BAS/1/1072-01-01 to S.A; L.S.G.C. was supported by a Juan de la Cierva Formación fellowship funded by the Spanish Ministry of Science, Innovation and Universities at the King Juan Carlos University of Madrid, Spain.

\section{LITERATURE CITED}

Agustí S, Regaudie-de-Gioux A, Arrieta JM, Duarte CM (2014) Consequences of UV-enhanced community respiration for plankton metabolic balance. Limnol Oceanogr 59:223-232

Agustí S, Llabrés M, Carreja B, Fernández M, Duarte CM (2015) Contrasting sensitivity of marine biota to UV-B radiation between Southern and Northern Hemispheres. Estuaries Coasts 38:1126-1133

Agusti S, Vigoya L, Duarte CM (2018) Annual plankton community metabolism in estuarine and coastal waters in Perth (Western Australia). PeerJ 6:e5081

Arrieta JM, Weinbauer MG, Herndl GJ (2000) Interspecific variability in sensitivity to UV radiation and subsequent recovery in selected isolates of marine bacteria. Appl Environ Microbiol 66:1468-1473

*Ball WT, Alsing J, Mortlock DJ, Staehelin J and others (2018) Evidence for a continuous decline in lower stratospheric ozone offsetting ozone layer recovery. Atmos Chem Phys 18:1379-1394

*Banaszak AT, Neale PJ (2001) Ultraviolet radiation sensitivity of photosynthesis in phytoplankton from an estuarine environment. Limnol Oceanogr 46:592-603

* Barbieri ES, Villafane VE, Helbling EW (2002) Experimental assessment of UV effects on temperate marine phytoplankton when exposed to variable radiation regimes. Limnol Oceanogr 47:1648-1655

Beardall J, Stojkovic S, Gao K (2014) Interactive effects of nutrient supply and other environmental factors on the sensitivity of marine primary producers to ultraviolet radiation: implications for the impacts of global change. Aquat Biol 22:5-23

Behrenfeld M, Hardy J, Gucinski H, Hanneman A, Lee H, Wones A (1993a) Effects of ultraviolet-B radiation on primary production along latitudinal transects in the South Pacific ocean. Mar Environ Res 35:349-363

Behrenfeld MJ, Chapman JW, Hardy JT, Lee H II (1993b) Is there a common response to ultraviolet-B radiation by marine phytoplankton? Mar Ecol Prog Ser 102:59-68

Bertoni R, Jeffrey WH, Pujo-Pay M, Oriol L, Conan P, Joux F (2011) Influence of water mixing on the inhibitory effect of UV radiation on primary and bacterial production in Mediterranean coastal water. Aquat Sci 73:377-387

* Boucher NP, Prézelin BB (1996) An in situ biological weighting function for UV inhibition of phytoplankton carbon fixation in the Southern Ocean. Mar Ecol Prog Ser 144: 223-236

* Cabrerizo MJ, Carrillo P, Villafañe VE, Walter Helbling E (2014) Current and predicted global change impacts of UVR, temperature and nutrient inputs on photosynthesis and respiration of key marine phytoplankton groups. J Exp Mar Biol Ecol 461:371-380

Carpenter JH (1965) The accuracy of the Winkler method for dissolved oxygen analysis. Limnol Oceanogr 10: $135-140$

* Carrillo P, Medina-Sánchez JM, Herrera G, Durán C and others (2015) Interactive effect of UVR and phosphorus on the coastal phytoplankton community of the Western Mediterranean Sea: unravelling eco-physiological mechanisms. PLOS ONE 10:e0142987

Conan P, Joux F, Torréton JP, Pujo-Pay M, Douki T, RochelleNewall E, Mari X (2008) Effect of solar ultraviolet radiation on bacterio- and phytoplankton activity in a large coral reef lagoon (southwest New Caledonia). Aquat Microb Ecol 52:83-98

Cullen JJ, Lesser MP (1991) Inhibition of photosynthesis by ultraviolet radiation as a function of dose and dosage rate: results for a marine diatom. Mar Biol 111:183-190

del Giorgio PA, Williams, PJ (2005) Respiration in aquatic ecosystems. Oxford University Press, Oxford

Farman JC, Gardiner BG, Shanklin JD (1985) Large losses of total ozone in Antarctica reveal seasonal $\mathrm{ClOx} / \mathrm{NOx}$ interaction. Nature 315:207-210

*Forster RM, Schubert H (2001) The effects of ultraviolet radiation on the planktonic community of a shallow, eutrophic estuary: results of mesocosm experiments. Helgol Mar Res 55:23-34

Fritz JJ, Neale PJ, Davis RF, Peloquin JA (2008) Response of Antarctic phytoplankton to solar UVR exposure: inhibi- 
tion and recovery of photosynthesis in coastal and pelagic assemblages. Mar Ecol Prog Ser 365:1-16

Fuentes-Lema A, Sobrino C, González N, Estrada M, Neale PJ (2015) Effect of solar UVR on the production of particulate and dissolved organic carbon from phytoplankton assemblages in the Indian Ocean. Mar Ecol Prog Ser 535:47-61

*García-Corral LS, Agustí S, Regaudie-de-Gioux A, Iuculano F, Carrillo-de-Albornoz P, Wassmann P, Duarte CM (2014) Ultraviolet radiation enhances Arctic net plankton community production. Geophys Res Lett 41:5960-5967

García-Corral LS, Martinez-Ayala J, Duarte CM, Agusti S (2015) Experimental assessment of cumulative temperature and UV-B radiation effects on Mediterranean plankton metabolism. Front Mar Sci 2:48

*arcía-Corral LS, Holding JM, Carrillo-de-Albornoz P, Steckbauer A and others (2017) Effects of UVB radiation on net community production in the upper global ocean. Glob Ecol Biogeogr 26:54-64

Garde K, Cailliau C (2000) The impact of UV-B radiation and different PAR intensities on growth, uptake of ${ }^{14} \mathrm{C}$, excretion of DOC, cell volume, and pigmentation in the marine prymnesiophyte, Emiliania huxleyi. J Exp Mar Biol Ecol 247:99-112

Godoy N, Canepa A, Lasternas S, Mayol E and others (2012) Experimental assessment of the effect of UVB radiation on plankton community metabolism along the Southeastern Pacific off Chile. Biogeosciences 9:1267-1276

Häder DP (2011) Does enhanced solar UV-B radiation affect marine primary producers in their natural habitats? Photochem Photobiol 87:263-266

Häder DP, Kumar HD, Smith RC, Worrest RC (2007) Effects of solar UV radiation on aquatic ecosystems and interactions with climate change. Photochem Photobiol Sci 6: 267-285

* Harrison JW, Silsbe GM, Smith REH (2015) Photophysiology and its response to visible and ultraviolet radiation in freshwater phytoplankton from contrasting light regimes. J Plankton Res 37:472-488

Helbling EW, Zagarese H (2003) UV effects in aquatic organisms and ecosystems. Royal Society of Chemistry, Cambridge

*Helbling EW, Villafañe V, Ferrario M, Holm-Hansen O (1992) Impact of natural ultraviolet radiation on rates of photosynthesis and on specific marine phytoplankton species. Mar Ecol Prog Ser 80:89-100

Herman JR (2010) Global increase in UV irradiance during the past 30 years (1979-2008) estimated from satellite data. J Geophys Res 115:D04203

Herndl GJ, Müller-Niklas G, Frick J (1993) Major role of ultraviolet-B in controlling bacterioplankton growth in the surface layer of the ocean. Nature 361:717-719

*Holm-Hansen O, Helbling EW, Lubin D (1993) Ultraviolet radiation in Antarctica: inhibition of primary production. Photochem Photobiol 58:567-570

* Huot Y, Jeffrey WH, Davis RF, Cullen JJ (2000) Damage to DNA in bacterioplankton: a model of damage by ultraviolet radiation and its repair as influenced by vertical mixing. Photochem Photobiol 72:62-74

Jeffrey WH, Aas P, Lyons MM, Coffin RB, Pledger RJ, Mitchell DL (1996) Ambient solar radiation-induced photodamage in marine bacterioplankton. Photochem Photobiol 64:419-427

Jokiel PL, York RH (1984) Importance of ultraviolet radiation in photoinhibition of microalgal growth. Limnol Oceanogr 29:192-198
Kaiser E, Herndl GJ (1997) Rapid recovery of marine bacterioplankton activity after inhibition by UV radiation in coastal waters. Appl Environ Microbiol 63: 4026-4031

Kataria S, Jajoo A, Guruprasad KN (2014) Impact of increasing Ultraviolet-B (UV-B) radiation on photosynthetic processes. J Photochem Photobiol B 137:55-66

Keller AA, Hargraves P, Jeon H, Klein-MacPhee G, Klos E, Oviatt C, Zhang J (1997) Effects of ultraviolet-B enhancement on marine trophic levels in a stratified coastal system. Mar Biol 130:277-287

Li G, Gao K, Gao G (2011) Differential impacts of solar UV radiation on photosynthetic carbon fixation from the coastal to offshore surface waters in the South China Sea. Photochem Photobiol 87:329-334

Litchman E, Neale PJ (2005) UV effects on photosynthesis, growth and acclimation of an estuarine diatom and cryptomonad. Mar Ecol Prog Ser 300:53-62

K Litchman E, Neale PJ, Banaszak AT (2002) Increased sensitivity to ultraviolet radiation in nitrogen-limited dinoflagellates: photoprotection and repair. Limnol Oceanogr 47:86-94

*Llabrés M, Agustí S (2006) Picophytoplankton cell death induced by UV radiation: evidence for oceanic Atlantic communities. Limnol Oceanogr 51:21-29

*labrés M, Agustí S, Alonso-Laita P, Herndl GJ (2010) Synechococcus and Prochlorococcus cell death induced by UV radiation and the penetration of lethal UVR in the Mediterranean Sea. Mar Ecol Prog Ser 399:27-37

* Llabrés M, Agustí S, Fernández M, Canepa A, Maurin F, Vidal F, Duarte CM (2013) Impact of elevated UVB radiation on marine biota: a meta-analysis. Glob Ecol Biogeogr 22:131-144

Molina MJ, Rowland FS (1974) Stratospheric sink for chlorofluoromethanes: chlorine atom-catalysed destruction of ozone. Nature 249:810-812

Montecino V, Pizarro G (1995) Phytoplankton acclimation and spectral penetration of UV irradiance off the central Chilean coast. Mar Ecol Prog Ser 121:261-269

Mora SD, Demers S, Vernet M (2000) The effects of UV radiation in the marine environment. Cambridge University Press, New York, NY

Moran MA, Zepp RG (1997) Role of photoreactions in the formation of biologically labile compounds from dissolved organic matter. Limnol Oceanogr 42:1307-1316

* Müller-Niklas G, Heissenberger A, Puskaric S, Herndl GJ (1995) Ultraviolet-B radiation and bacterial metabolism in coastal waters. Aquat Microb Ecol 9:111-116

Navarro E, Robinson CT, Behra R (2008) Increased tolerance to ultraviolet radiation (UVR) and cotolerance to cadmium in UVR-acclimatized freshwater periphyton. Limnol Oceanogr 53:1149-1158

*Navarro NP, Mansilla A, Figueroa FL, Korbee N, Jofre J, Plastino E (2014) Short-term effects of solar UV radiation and $\mathrm{NO}_{3}{ }^{-}$supply on the accumulation of mycosporinelike amino acids in Pyropia columbina (Bangiales, Rhodophyta) under spring ozone depletion in the sub-Antarctic region, Chile. Bot Mar 57:9-20

Neale PJ, Thomas BC (2017) Inhibition by ultraviolet and photosynthetically available radiation lowers model estimates of depth-integrated picophytoplankton photosynthesis: global predictions for Prochlorococcus and Synechococcus. Glob Change Biol 23:293-306

Neale PJ, Pritchard AL, Ihnacik R (2014) UV effects on the primary productivity of picophytoplankton: biological 
weighting functions and exposure response curves of Synechococcus. Biogeosciences 11:2883-2895

Ogbebo FE, Ochs C (2008) Bacterioplankton and phytoplankton production rates compared at different levels of solar ultraviolet radiation and limiting nutrient ratios. J Plankton Res 30:1271-1284

* Oudot C, Gerard R, Morin P, Gningue I (1988) Precise shipboard determination of dissolved oxygen (Winkler Procedure) for productivity studies with a commercial system. Limnol Oceanogr 33:146-150

Regaudie-de-Gioux A, Agustí S, Duarte CM (2014) UV sensitivity of planktonic net community production in ocean surface waters. J Geophys Res Biogeosci 119:929-936

Sass L, Spetea C, Máté Z, Nagy F, Vass I (1997) Repair of UV$B$ induced damage of Photosystem II via de novo synthesis of the $\mathrm{D}_{1}$ and $\mathrm{D}_{2}$ reaction centre subunits in Synechocystis sp. PCC 6803. Photosynth Res 54:55-62

Schlitzer R (2013) Ocean Data View. http://odv.awi.de.

Seckmeyer G, McKenzie RL (1992) Increased ultraviolet radiation in New Zealand $\left(45^{\circ} \mathrm{S}\right)$ relative to Germany $\left(48^{\circ} \mathrm{N}\right)$. Nature 359:135-137

Sen Mandi S (2016) Natural UV radiation in enhancing survival value and quality of plants. Springer India, New Delhi

Shang JL, Zhang ZC, Yin XY, Chen M and others (2018) UV$B$ induced biosynthesis of a novel sunscreen compound in solar radiation and desiccation tolerant cyanobacteria. Environ Microbiol 20:200-213

Smith RC, Baker KS (1989) Stratospheric ozone, middle ultraviolet radiation and phytoplankton productivity. Oceanography 2:4-11

Sobrino C, Montero O, Lubián LM (2004) UV-B radiation increases cell permeability and damages nitrogen incorporation mechanisms in Nannochloropsis gaditana. Aquat Sci 66:421-429

Tedetti M, Sempéré R (2006) Penetration of ultraviolet radiation in the marine environment. A review. Photochem Photobiol 82:389-397

Vass I, Sass L, Spetea C, Bakou A, Ghanotakis DF, Petrouleas V (1996) UV-B-induced inhibition of photosystem II electron transport studied by EPR and chlorophyll fluorescence. Impairment of donor and acceptor side components. Biochemistry 35:8964-8973

Villafañe VE, Sundbäck K, Figueroa FL, Helbling EW (2003) Photosynthesis in the aquatic environment as affected by
UVR. In: Helbling EW, Zagarese H (eds) UV effects in aquatic organisms and ecosystems. The Royal Society of Chemistry, Cambridge, p 357-397

*Villafañe VE, Barbieri ES, Helbling EW (2004) Annual patterns of ultraviolet radiation effects on temperate marine phytoplankton off Patagonia, Argentina. J Plankton Res 26:167-174

*Villafañe VE, Janknegt PJ, de Graaff M, Visser RJW, van de Poll WH, Buma AGJ, Helbling EW (2008) UVR-induced photoinhibition of summer marine phytoplankton communities from Patagonia. Mar Biol 154:1021-1029

*Villafañe VE, Cabrerizo MJ, Erzinger GS, Bermejo P, Strauch SM, Valiñas MS, Helbling EW (2017) Photosynthesis and growth of temperate and sub-tropical estuarine phytoplankton in a scenario of nutrient enrichment under solar ultraviolet radiation exposure. Estuaries Coasts 40:842-855

*Wängberg SÅ, Garde K, Gustavson K, Selmer JS (1999) Effects of UVB radiation on marine phytoplankton communities. J Plankton Res 21:147-166

WWeatherhead EC, Andersen SB (2006) The search for signs of recovery of the ozone layer. Nature 441:39-45

*Weinbauer MG, Wilhelm SW, Suttle CA, Garza DR (1997) Photoreactivation compensates for UV damage and restores infectivity to natural marine virus communities. Appl Environ Microbiol 63:2200-2205

*Wilhelm SW, Jeffrey WH, Dean AL, Meador J, Pakulski JD, Mitchell DL (2003) UV radiation induced DNA damage in marine viruses along a latitudinal gradient in the southeastern Pacific Ocean. Aquat Microb Ecol 31:1-8

Williamson CE, Neale PJ, Hylander S, Rose KC and others (2019) The interactive effects of stratospheric ozone depletion, UV radiation, and climate change on aquatic ecosystems. Photochem Photobiol Sci 18:717-746

World Meteorological Organization (2019) WMO Statement on the state of the global climate in 2018. Publications Board, WMO, Geneva

Y Yamamoto Y (2016) Quality control of photosystem II: The mechanisms for avoidance and tolerance of light and heat stresses are closely linked to membrane fluidity of the thylakoids. Front Plant Sci 7:1136

Kepp RG, Erickson DJ III, Paul ND, Sulzberger B (2007) Interactive effects of solar UV radiation and climate change on biogeochemical cycling. Photochem Photobiol Sci 6:286-300 
Appendix 1. Additional data
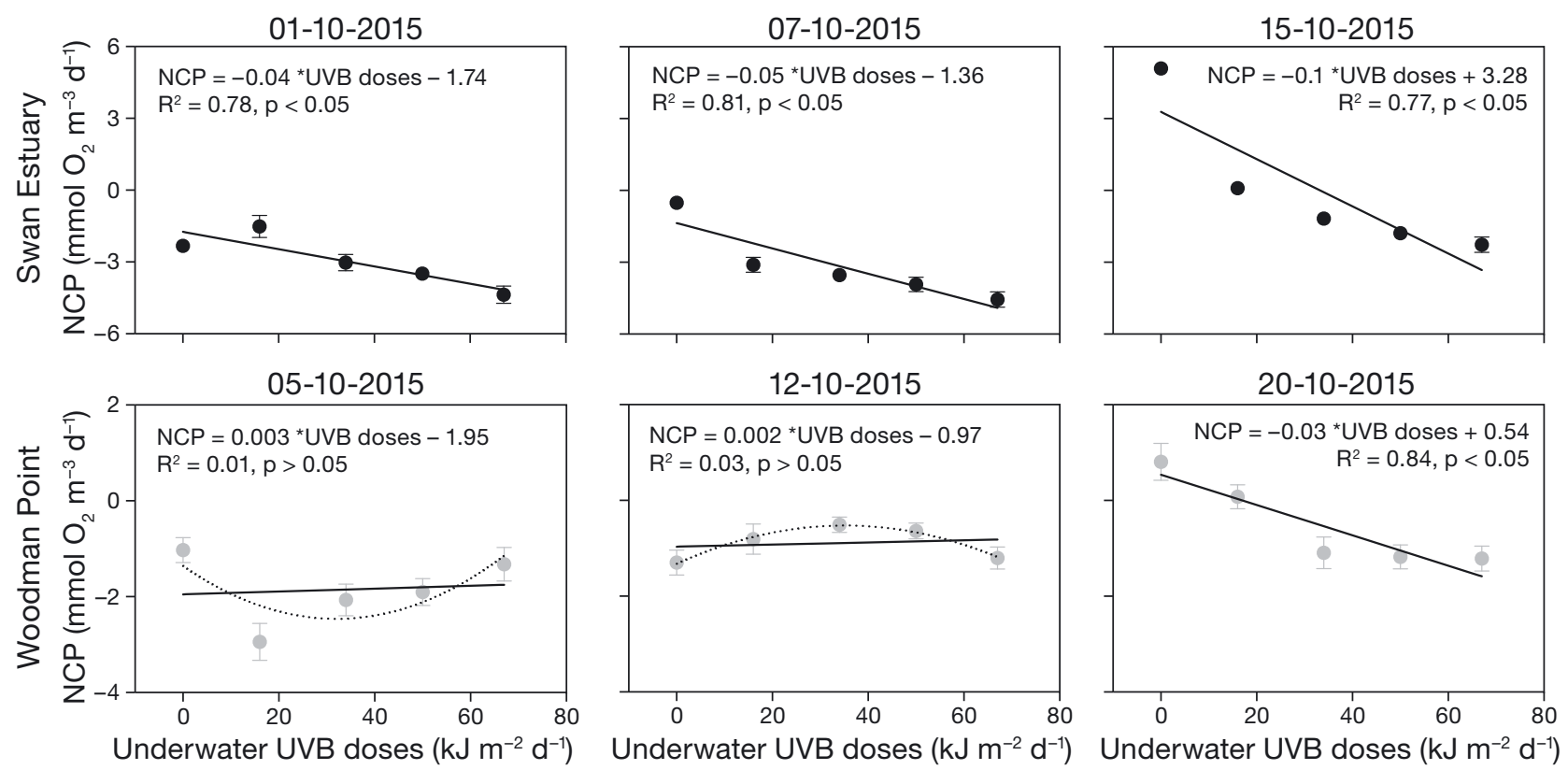

Fig. A1. Responses of net community production (NCP; mean \pm SEM) to an experimental gradient of increasing underwater UVB daily doses (UVB from lamps + photosynthetically active radiation, PAR), tested on plankton communities from the Swan Estuary (black dots, upper panel) and Woodman Point (grey dots, lower panel). The solid lines indicate the fitted Type II linear regression for each experiment and the dotted curves represent the best fitting second-order polynomial regression. NCP at dose $=0$ represents communities exposed only to PAR (NCP-uv)

Editorial responsibility: Steven Morgan, Bodega Bay, California, USA
Submitted: February 6, 2020; Accepted: August 3, 2020

Proofs received from author(s): September 20, 2020 